\title{
Christophe Falin, Shanghai - Hong Kong, villes de cinéma (Shanghai - Hong Kong, cities of cinema),
}

Paris, Armand Colin, 2014, 168 pp.

Luisa Prudentino

Translator. Will Thornely

\section{OpenEdition}

12 Journals

Electronic version

URL: http://journals.openedition.org/chinaperspectives/6741

DOI: 10.4000/chinaperspectives.6741

ISSN: 1996-4617

Publisher

Centre d'étude français sur la Chine contemporaine

Printed version

Date of publication: 1 June 2015

Number of pages: 65-66

ISSN: 2070-3449

Electronic reference

Luisa Prudentino, «Christophe Falin, Shanghai - Hong Kong, villes de cinéma (Shanghai - Hong Kong, cities of cinema), », China Perspectives [Online], 2015/2 | 2015, Online since 01 January 2017, connection on 24 September 2020. URL : http://journals.openedition.org/chinaperspectives/6741 DOI : https://doi.org/10.4000/chinaperspectives.6741 
not consist of fomenting revolution or fighting for democracy, but rather of protecting workers' interests within the existing system. For Han, democracy essentially consists of resolving concrete problems, especially through collective bargaining. Two recurring themes run through the book: on the one hand, distrust of ideology, especially grand theories on democracy, abstract objectives in whose name individual interests could be sacrificed; and on the other, the idea that effective action must necessarily be apolitical, that is to say, an action that helps to identify the meeting point for the interests of all party - workers, employers, and the authorities. To those who hoped he would become China's Walesa, Han's response is that the country has to find its own path and he abides by pragmatism: ex nihilo formation of independent unions is not a prerequisite for the emergence of collective bargaining; in practice, independent unions will emerge through such collective bargaining and from reforms within official unions.

$\mathrm{CLB}$ is thus representative of the new civil society born at the turn of the century, rising from the ashes of the 1989 Democracy Movement. Whereas that movement was characterised by demands for abstract rights, the current effort is toward the emergence of practical rights through their concrete exercise. It is also about taking into account - instead of ignoring the constraints of the authoritarian system to pursue a "constructive dialogue" with the party-state - which should also keep its part of the bargain - for defending the rights of individuals within the system itself. But will a civil society that seeks to abandon all political messages manage to have a political impact some day? Rejecting opposition and systematically pursuing compromises and win-win solutions that serve to smooth out social and political contradictions could merely lead to a dose of "harmonious democracy" that helps the regime preserve itself even longer...

Despite a relatively large number of typographical errors, anglicisms, and some repetition, Mon combat pour les ouvriers chinois is a reference text on more than one score: it provides a valuable account of militant activity in China and Hong Kong and of the evolution in the conditions of Chinese workers, especially stressing that they have become full-scale actors in the defence of their rights. It also raises fundamental questions concerning the role of workers and of civil society in the evolution of the Chinese regime.

I Translated by N. Jayaram.

IChloé Froissart is director of the Sino-French Academic Centre

(CFC), Tsinghua University, Beijing, and a researcher at CEFC, Hong Kong (chloefroissart@cefc.com.hk).

\footnotetext{
**This book review's digital version was updated on 30/10/2015 to edit slight translation inaccuracies**
}

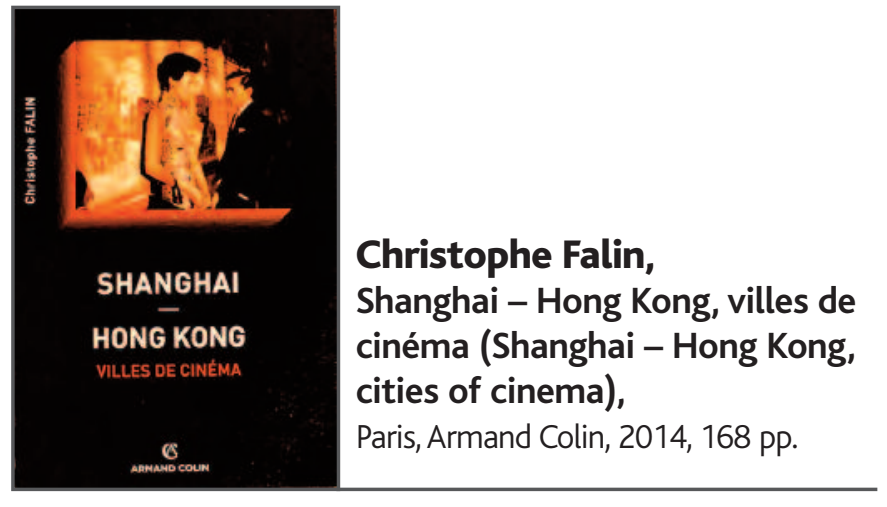

\section{LUISA PRUDENTINO}

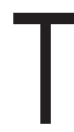
his work is dedicated to Shanghai and Hong Kong, two cities that occupy a mythical position in the eyes of the West and in Chinese cinema as, respectively, the birthplace of the industry in China and the place where it developed. Through their dual material and symbolic significance, the two cities continue to contribute to the history of cinema to this day.

The author has divided the book into three sections. The first is given over to the history of Chinese cinema in the two cities, and in particular to the exchanges that took place between the two over the course of the twentieth century. In this section, Christophe Falin reveals the major events that resulted in these exchanges, from the birth of sound film to the handover of Hong Kong to China in 1997, also observing the Sino-Japanese War (1937-1945) and the Communist victory of 1949. This section also includes an interesting paragraph concerning the mixing of Chinese cinema in the 1950s, resulting from the creation of two flagship companies in Hong Kong, MP\&GI and Shaw Brothers, which made this city into one of the most important centres for film production in Asia. Of course, the importance of these two studios in Hong Kong cinema at the time (and even afterwards) is well known, but there is precious little awareness of the strategic role they played in the distribution of film throughout Southeast Asia as a whole. From Malaysia to Singapore, every step in the creation of a film was controlled by these two companies, from the producers and directors through to the scriptwriters, actors, and technicians.

The second section covers the many ways in which Shanghai and Hong Kong have been portrayed in Chinese and Western films since the 1930s. The aim of the author is to show how the urban planning of the two cities has helped create an image of the two that is as real as it is fantastic. The reader is taken on a tour of Shanghai's 1930s lilong, which were, according to the author's definition, "aligned rows of two-level houses, built from brick," thus revealing both the luxurious properties of the foreign concessions and also the extreme poverty of the city's slums. The chapter covering Hong Kong and its overpopulated and hyperactive neighbourhood of Tsim Sha Tsui, which has provided the backdrop for many Chinese and foreign thrillers, contains even richer descriptions.

Finally, the third section is given over, in particular, to three major directors with close links to their cities: Lou Ye of Shanghai, and Wong Kar-wai and Johnnie To of Hong Kong. The author portrays Lou Ye as the natural heir to the generation of Chinese urban film-makers who emerged at the start of the 1990s, following the crackdown on the student movement at Tiananmen Square. Lou Ye's portrayal of Shanghai, the city of his birth, is lucid, even disillusioned. Wong Kar-wai, meanwhile, has a more intense bond with 
the city of Hong Kong, capturing "its heartbeat and its beauty." In Johnnie To's films, on the other hand, Hong Kong is a more tangible presence, and each feature film provides the film-maker with the opportunity to show several different faces of the territory.

Falin adopts two approaches in his book: the history of cinema in the two cities, and the study of how they are portrayed in film. Although the combination of these two approaches allows the many links between the two cities and their film-making to be approached in an original and complimentary manner, it also gives rise to a number of repetitions, especially in terms of film titles and historical facts, which ultimately weigh down the text. This is felt especially strongly in the first section of the work, in which the task of recounting the intertwined histories of the various film studios has led the author to make so many cross-references between the two cities and their film-making heritages that the pace of the narration is sometimes broken.

The second section, on the other hand, is far more fluid and effective; that said, while it is understandable that the author is not able to delve deeply into the various aspects of how the cities of Shanghai and Hong Kong are portrayed in film, it is unfortunate that certain fundamental films are not cited (such as Jacob Cheung's Cageman) or are only covered fleetingly (for example, I wish I knew, by Jia Zhangke) rather than being the subject of greater reflection and analysis.

The eighth chapter of the third and final section of the work also contains a few repetitions before offering portraits of the three major directors mentioned above (Lou Ye, Wong Kar-wai, and Johnnie To). Falin's analysis of the impact their film-making has had on the imaginary and social representation of the two cities is astute and pertinent.

An exhaustive and detailed bibliography concludes the work, and will doubtless prove very useful to any readers wishing to make their own contribution to research into relations between cities and film, an area that the author currently considers to be excessively "Eurocentric."

\section{Translated by Will Thornely.}

I Luisa Prudentino is professor of Chinese language and civilisation at the University of Salento (Lecce, Italy) and lecturer in history of Chinese cinema at INALCO (Paris, France), the University of Artois (Arras, France) and the University of Lorraine (Metz, France) (luisaprudentino@free.fr).

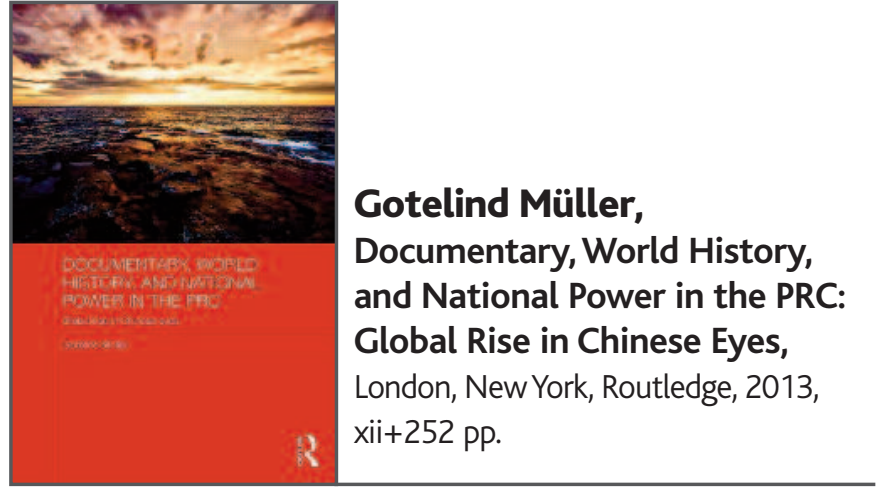

\section{YVES RUSSELL}

( otelind Müller has for a number of years been studying the formation of Chinese historical consciousness and, more specifically, the way in which conceptions of the national Self and the foreign Other are conveyed through representations of history. It was this research that led her to carry out a detailed analysis of Zou Xiang Gonghe (Towards the Republic), which was broadcast in 2003 on the state channel CCTV, and to then study the way in which foreign and, more particularly, European history have been covered in various academic curricula in China since 1900. (1)

In Documentary, World History, and National Power in the PRC, Müller returns to televisual analysis, studying three historical documentaries broadcast in multiple episodes in China between 2006 and 2007: Daguo jueqi 大 国崛起, Fuxing zhi lu 复兴之路, and Ju an si wei 居安思危, which she chose to translate into English respectively as The Rise of the Great Powers, The Road to Revival, and Alert to Danger while Dwelling in Safety.

The author argues convincingly that by studying these three documentaries produced by state institutions, it becomes possible to grasp "the ways in which the Chinese officially favoured view of history is transmitted via the media so as to guide perceptions of foreign and Chinese history towards legitimization of PRC policies" (p. 4). It can be seen that the author views the documentaries as three moves made by the Chinese state in the same game in order to legitimise its political agenda. By focusing on the rise of nine "great nations" (daguo 大国) - Spain, Portugal, the Netherlands, Great Britain, France, Germany, Japan, Russia, and the United States - since the fifteenth century, Daguo jueqi shows that "What is to be learned from history is therefore only what a country needs in order to 'rise'" (p. 8). Fuxing zhi lu recounts the history of China since 1840 from the perspective of its "revival," allowing China to be tied in with the history of the great nations while setting it apart. Ju an si wei, whose full title is "Alert to Danger while Dwelling in Safety: The historical lesson of the perishing of the Soviet Communist Party" (Ju an si wei - Sugong wangdang de lishi jiaoxun 居安思危 一 苏共亡党的历史教训), shows what China (or rather the CCP) needs to avoid (p. 8).

One could quibble endlessly on the choice of these three documentaries or even on the influence of the documentary format on the popular historical consciousness. In the introduction (Chapter One), Müller justifies her choice by pointing to the increasing success of the documentary format with the Chinese public, and in particular the aura of objectivity and scientificity it enjoys (p. 1). The three documentaries studied also allow three 